\title{
Prevalence of head and neck cancer in the Eugenio Espejo Specialties Hospital, period 2002-2015, Quito, Ecuador
}

\author{
Mayra E. Paltas-Miranda ${ }^{1 *}$, Ahmad W. Mushtaq-Wali ${ }^{2}$ and Ma. Gabriela Haye-Biazevic ${ }^{3}$ \\ ${ }^{1}$ Faculty of Dentistry, Universidad Central del Ecuador, Quito, Ecuador; ${ }^{2}$ Oncology Department, Hospital Eugenio Espejo, Quito, Ecuador; ${ }^{3}$ Faculty \\ of Dentistry, University of São Paulo, São Paulo, Brazil
}

\begin{abstract}
Objective: To determine the prevalence of head and neck cancer in the Oncology Service of the Eugenio Espejo Hospital, from 2002 to 2015. Methods: This is an epidemiological, analytical and cross-sectional study, the data was retrieved from the medical records of patients who were treated with head and neck cancer, all data was collected and transcribed onto an Excel spreadsheet, then coded and analyzed in STATA version 14.0. Descriptive Statistics and the Chi-square and Poisson tests were used with a level of significance of $0.05 \%$ at a level of confidence of $95 \%$. Results: There was a prevalence in female gender of $50.7 \%$, the age from 50 to 60 years represented $20.3 \%$, level of education (elementary) with $53.1 \%$, place of residence (highlands) with $76.7 \%$, occupation household chores with $38.4 \%$, anatomical region oral cavity $36.4 \%$, under surgical treatment $38.9 \%$, the time of hospital treatment from 1 to 180 days $44.5 \%$ and $31.8 \%$ of the patients finished the treatment. Conclusions: Head and neck cancer prevailed in the female gender in the age of 55, \pm 5 years, most were from the Andean Mountain (Sierra) region with low level of instruction and whom perform household chores, The oral cavity was the most affected anatomical region.
\end{abstract}

Key words: Cancer. Head and neck. Treatment. Epidemiology.

\section{Prevalencia del cáncer de cabeza y cuello en el Hospital de Especialidades Eugenio Espejo en el periodo 2002-2015 en Quito, Ecuador}

\section{Resumen}

Objetivo: Determinar la prevalencia de cáncer de cabeza y cuello en el Servicio de Oncología del Hospital de Especialidades Eugenio Espejo, periodo 2002 al 2015. Métodos: Es un estudio epidemiológico, analítico y transversal; Ios datos fueron tomados de las historias clínicas de pacientes atendidos con cáncer de cabeza y cuello, fueron registrados en una planilla de Excel, codificados y analizados en el paquete de estadística STATA versión 14.0, estadística descriptiva, los test de Chi cuadrada y de Poisson, con un nivel de significancia 0.05\% y una confiabilidad del 95\%. Resultados: Existió una prevalencia discreta en sexo femenino con el 50.7\%, la edad de 50-60 años el 20.3\%, nivel de educación (primaria) el 53.1\%, residencia «sierra» el 76.7\%, ocupación quehaceres domésticos el 38.4\%; la región anatómica cavidad bucal (36.4\%); el tratamiento quirúrgico fue el 38.9\%; tiempo de tratamiento hospitalario (de 1 a 180 días) el 44.5\% y el 31.8\% finalizó el tratamiento. Conclusiones: El cáncer de cabeza y cuello prevaleció más en el sexo femenino entre la edad de 55 años \pm 5 años. La mayoría era de la región sierra, con bajo nivel de instrucción, y realizaban quehaceres domésticos. La cavidad bucal fue la región anatómica más afectada.

Palabras clave: Cáncer. Cabeza y cuello. Tratamiento. Epidemiología.

\section{Correspondence:}

*Mayra E. Paltas-Miranda

E-mail: mayelhy9@hotmail.com
Date of reception: 15-04-2020

Date of acceptance: 28-03-2021

DOI: 10.24875/j.gamo.M21000208
Available online: 18-06-2021 Gac Mex Oncol. 2021;20(3):17-25 www.gamo-smeo.com 1665-9201/@ 2021 Sociedad Mexicana de Oncología. Published by Permanyer. This is an open access article under the terms of the CC BY-NC-ND license (http://creativecommons.org/licenses/by-nc-nd/4.0/). 


\section{Introduction}

Cancer is a public health problem that affects the entire world. It is a disease characterized by an alteration or mutation of normal regulatory genes; this phenomenon leads to the development of cancer cells with the ability to invade and destroy adjacent tissues, as well as to metastasize to other organs $\mathbf{s}^{1,2}$.

Head and neck cancers can be the result of exposure to multiple risk factors ${ }^{3}$. These neoplasms are lesions with many differences in their incidence, origin of the tumor, clinical form, evolution, treatment and prognosis ${ }^{4,5}$. Both prevalence and incidence, as well as mortality, considerably vary in different parts of the world ${ }^{6,7}$. Head and neck cancers can compromise different anatomical regions, such as the lips, oral cavity, pharynx, larynx, paranasal sinuses and salivary glands ${ }^{8,9}$.

According to the World Health Organization (WHO), cancers of the oral cavity and oropharynx are the most common head and neck neoplasms $8,10,11$. Head and neck cancer has had a highly important incidence in the past two decades, and has become the sixth leading cause of death in the world 5 ,12,13, with 650,000 new cases diagnosed every year and 300,000 deaths from this condition recorded in the same period, accounting for $5 \%$ of all malignant neoplasms $8,14,15$. It has an incidence that is twice higher in males with regard to females; smoking alone or together with alcohol consumption is the main cause of head and neck cancer; the most affected age is $60 \pm 5$ years ${ }^{16,17}$. Squamous cell carcinoma and its variants is the most common histological type and the cause of $90 \%$ of all head and neck neoplasms $\mathbf{s}^{6,9,18}$.

Regarding the prevalence of head and neck cancer over a five-year period, according to data reported by GLOBOCAN 2012, developing countries account for $62.2 \%$, and developed countries, for $37.7 \%^{10,19}$. There is a higher incidence in Asia (57.6\%), followed by Europe (20.3\%), North America (8.4\%), Latin America and the Caribbean $(7.0 \%)$, Africa $(5.8 \%)$ and Oceania (0.9\%). The mortality rate is $65.9 \%$ in Asia, $16.8 \%$ in Europe, $6.7 \%$ in Africa, $6.4 \%$ in Latin America and the Caribbean, $3.7 \%$ in North America and $0.5 \%$ in Oceania ${ }^{10,20}$.

Latin America is characterized by a high prevalence and incidence of head and neck cancer, with great variation between countries. Of all new cases in the world, $6.5 \%$ occur in South and Central America ${ }^{21}$, with the countries with the highest incidence of oral cavity cancer being Cuba, Brazil, Uruguay and Puerto Rico ${ }^{10,15}$.
Head and neck cancer elevated incidence can certainly be driven by greater population growth and aging, and also by lifestyle behavioral changes such as tobacco and alcohol consumption habits, poor diet, physical inactivity and certain sexual behaviors early in life ${ }^{20}$.

Occupational risks have a cumulative effect over time, conferring robustness to epidemiological data of a higher prevalence in patients older than 50 years, which makes many authors claim that age is the main risk factor for the development of cancer, especially in the oral cavity ${ }^{22}$. Prolonged exposure to ultraviolet radiation and some chemicals, accompanied by individual genetic susceptibility, are high risk factors for the development of cancer in the upper aerodigestive region ${ }^{4}$.

Head and neck cancer clinical manifestations are quite varied and mainly depend on tumor location, size of the primary tumor mass, presence or absence of lymph node compromise and invasion of adjacent structures; paresthesia, pain, hemorrhage, ulcers, sore throat, dysphagia and weight loss can occur ${ }^{4,14}$, which cause serious consequences on patient health and can lead to large mutilations and physical and functional deformities that seriously affect psychological, economic, Social and family members in general, quality of life of patients who suffer from this disease ${ }^{23}$.

Treatment must be multidisciplinary and includes medical personnel, oncologists, physiotherapists, psychologists, maxillofacial specialists and even the help of family members. The type of treatment will depend on tumor stage, anatomical location and tumor size and whether or not there are metastases, always trying to preserve organ function; surgical treatment and radiotherapy are the most commonly used conventional procedures for head and neck cancers ${ }^{4,9,17}$.

Currently, there are statistical data on head and neck cancer from 2006 to 2010, reported by the SOLCA Quito National Registry of Tumors and data reported on cancer in general by the National Institute of Statistics and Censuses (INEC - Instituto Nacional de Estadísticas y Censos) ${ }^{24}$, but so far there are no studies on head and neck cancer conducted at state hospitals of Ecuador. The fact that the Eugenio Espejo Specialty Hospital is a national reference hospital that serves a large number of people with low educational level and economic resources, motivated us to carry out this study, the purpose of which is to determine the prevalence of head and neck cancer according to demographic conditions, cancer type and anatomical site, as well as treatment time and evolution. 


\section{Methods}

This was an epidemiological, analytical, cross-sectional study. This project was submitted to the Research and Teaching Bioethics Committee of the Eugenio Espejo Specialty Hospital and to the Human Research Ethics Committee of the School of Dentistry of the University of Sao Paulo.

All data were obtained from medical records of patients with head and neck cancer, who were cared for at the Oncology Department of the Eugenio Espejo Specialty Hospital over a 13-year period, from January 2002 to December 2015. A sample of 211 medical records was considered for this research, which corresponded to all the medical records of patients with head and neck cancer diagnosed by clinical and histological examination; all medical records that did not contain the data necessary for the research were excluded.

Patient demographic data were considered, including age, gender, level of education, place of residence and occupation. Data related to the type of head and neck cancer were considered according to the International Classification of Diseases, $10^{\text {th }}$ revision (ICD-10). Data related to tumor anatomical location, type of treatment received, hospital treatment time (for which the dates of hospital admission and discharge were considered) and head and neck cancer patient evolution (alive patients who completed treatment, those who died while on treatment, those who discontinued treatment, and those who were still on treatment) were also recorded.

All data were recorded in an Excel spreadsheet that allowed to prepare a database that was subsequently processed with the STATA statistical program, version 14.0. Descriptive statistics were used for absolute and relative frequencies, chi-square and Poisson tests were used with a level of significance of $0.05 \%$ at a confidence level of $95 \%$, to determine associations between variables.

\section{Results}

A total of 211 medical records were analyzed. The obtained results described shown below and in table 1,

A slight prevalence of the female gender is observed $(50.71 \%)$; the age group of 51 to 60 years accounts for $20.38 \%$; primary education, for $90.52 \%$; place of residence "sierra", for $76.78 \%$; and the household chores occupation accounts for $38.4 \%$, followed by farmer, with $22.7 \%$.
Table 1. Demographic frequencies distribution: gender, age, level of education, place of residence and occupation. Eugenio Espejo Specialty Hospital. 2002-2015

\begin{tabular}{|c|c|c|c|}
\hline Demographic variables & Frequency & Percentage & Cum. \\
\hline $\begin{array}{l}\text { Gender } \\
\text { Males } \\
\text { Females }\end{array}$ & $\begin{array}{l}104 \\
107\end{array}$ & $\begin{array}{l}49.29 \\
50.71\end{array}$ & $\begin{array}{c}49.29 \\
100\end{array}$ \\
\hline $\begin{array}{c}\text { Age (years) } \\
11-20 \\
21-30 \\
31-40 \\
41-50 \\
51-60 \\
61-70 \\
71-80 \\
81-93\end{array}$ & $\begin{array}{l}12 \\
16 \\
25 \\
26 \\
43 \\
30 \\
31 \\
18\end{array}$ & $\begin{array}{c}5.69 \\
12.32 \\
11.85 \\
12.32 \\
20.38 \\
14.22 \\
14.69 \\
8.53\end{array}$ & $\begin{array}{c}5.69 \\
18.01 \\
29.86 \\
42.18 \\
62.56 \\
76.78 \\
91.47 \\
100\end{array}$ \\
\hline $\begin{array}{l}\text { Level of education } \\
\text { None } \\
\text { Primary education } \\
\text { Secondary education } \\
\text { Higher education }\end{array}$ & $\begin{array}{c}33 \\
112 \\
46 \\
20\end{array}$ & $\begin{array}{l}15.6 \\
53.1 \\
21.8 \\
9.48\end{array}$ & $\begin{array}{c}15.6 \\
68.7 \\
90.5 \\
100\end{array}$ \\
\hline $\begin{array}{l}\text { Place of residence } \\
\text { Coast } \\
\text { Amazon } \\
\text { Sierra }\end{array}$ & $\begin{array}{c}39 \\
10 \\
162\end{array}$ & $\begin{array}{c}18.5 \\
4.7 \\
76.78\end{array}$ & $\begin{array}{l}18.5 \\
23.2 \\
100\end{array}$ \\
\hline $\begin{array}{l}\text { Occupation } \\
\text { Farmer/horticulturist/ } \\
\text { floriculturist } \\
\text { Household chores } \\
\text { Student } \\
\text { Trader } \\
\text { Professional area } \\
\text { Artisan }\end{array}$ & $\begin{array}{l}48 \\
\\
81 \\
25 \\
25 \\
11 \\
21\end{array}$ & $\begin{array}{c}22.7 \\
\\
38.4 \\
11.8 \\
11.8 \\
5.2 \\
10\end{array}$ & $\begin{array}{c}22.7 \\
\\
61.1 \\
73 \\
84.8 \\
90 \\
100\end{array}$ \\
\hline Total & 211 & 100.00 & \\
\hline
\end{tabular}

Table 2 shows that, according to ICD-10, the codes that prevail are: $\mathrm{C} 76.0$ (cancers involving broad regions), with 19.9\%, and C01-C02 (tongue cancer), with 18.5\%. The prevailing anatomical region is the oral cavity (36.5\%); the most prevalent treatment that was received is surgical (38.9\%); the most common hospital treatment time is from 1 to 180 days $(44.5 \%)$. As for treatment evolution, $34.1 \%$ continued on treatment, and $31.8 \%$ were alive and had completed treatment (Table 3).

Among the types of head and neck cancer, according to ICD-10 and demographic characteristics, the levels of significance are observed to be higher than 0.05 at a confidence level of $95 \%$; therefore, there is no association of any kind. However, for the place of residence, the level of significance is 0.049 , and there is a slight association with the types of cancer.

Table 4 shows that the significance levels are higher than $0.05 \%$, at a confidence level of $95 \%$; therefore, 
Table 2. Distribution of frequencies related to the type of head and neck cancer according to International Classification of Diseases (ICD-10) diagnoses, anatomical location, treatment received, hospital treatment time and treatment evolution. Eugenio Espejo Specialty Hospital. 2002-2015

\begin{tabular}{|c|c|c|c|}
\hline ICD-10 diagnosis & Frequency & Percentage & Cum. \\
\hline $\mathrm{COO}$ & 5 & 2.4 & 2.4 \\
\hline $\mathrm{CO1}, \mathrm{CO2}$ & 39 & 18.5 & 20.9 \\
\hline $\mathrm{CO3}$ & 11 & 5.2 & 26.1 \\
\hline $\mathrm{CO} 4, \mathrm{C} 05, \mathrm{C} 06.0, \mathrm{C} 06.2$ & 12 & 5.7 & 31.8 \\
\hline $\mathrm{CO7}, \mathrm{C} 08.0$ & 34 & 16.1 & 47.9 \\
\hline Co9, C10 & 21 & 10.0 & 57.8 \\
\hline C11, C310, C41.0 & 34 & 16.1 & 73.9 \\
\hline C14 & 13 & 6.2 & 80.1 \\
\hline C76.0 & 42 & 19.9 & 100.0 \\
\hline $\begin{array}{l}\text { Anatomical location } \\
\text { Head } \\
\text { Face } \\
\text { Oral cavity } \\
\text { Oropharynx } \\
\text { Nasopharynx } \\
\text { Salivary glands } \\
\text { Neck }\end{array}$ & $\begin{array}{c}6 \\
43 \\
77 \\
77 \\
21 \\
9 \\
34 \\
21\end{array}$ & $\begin{array}{c}2.8 \\
20.4 \\
36.5 \\
10.0 \\
4.3 \\
16.1 \\
10.0\end{array}$ & $\begin{array}{c}2.8 \\
23.2 \\
59.7 \\
69.7 \\
73.9 \\
90.0 \\
100.0\end{array}$ \\
\hline $\begin{array}{l}\text { Treatment received } \\
\text { Radiotherapy } \\
\text { Chemotherapy } \\
\text { Surgery } \\
\text { Chemotherapy, } \\
\text { radiotherapy, surgery } \\
\text { Radiotherapy and } \\
\text { surgery } \\
\text { Radiotherapy and } \\
\text { chemotherapy } \\
\text { Chemotherapy and } \\
\text { surgery } \\
\text { Palliative }\end{array}$ & $\begin{array}{c}2 \\
18 \\
82 \\
33 \\
\\
21 \\
21 \\
33 \\
\\
1\end{array}$ & $\begin{array}{r}0.9 \\
8.5 \\
38.9 \\
15.6 \\
10.0 \\
110.0 \\
15.6 \\
0.5\end{array}$ & $\begin{array}{r}0.9 \\
9.5 \\
48.3 \\
64.0 \\
73.9 \\
83.9 \\
99.5 \\
100.0\end{array}$ \\
\hline $\begin{array}{l}\text { Hospital treatment time } \\
1 \text { to } 180 \text { days } \\
181 \text { to } 365 \text { days } \\
366 \text { to } 730 \text { days } \\
731 \text { to } 4,931 \text { days }\end{array}$ & $\begin{array}{l}94 \\
39 \\
37 \\
41\end{array}$ & $\begin{array}{l}44.5 \\
18.5 \\
17.5 \\
19.4\end{array}$ & $\begin{array}{c}44.5 \\
63.0 \\
80.6 \\
100.0\end{array}$ \\
\hline $\begin{array}{l}\text { Treatment evolution } \\
\text { Continues on treatment } \\
\text { Alive, completed } \\
\text { treatment } \\
\text { Discontinued treatment } \\
\text { Died while on treatment }\end{array}$ & $\begin{array}{l}72 \\
67 \\
\\
54 \\
18\end{array}$ & $\begin{array}{c}34.1 \\
31.8 \\
\\
25.6 \\
8.5\end{array}$ & $\begin{array}{r}34.1 \\
65.9 \\
\\
91.5 \\
100.0\end{array}$ \\
\hline Total & 211 & 100.0 & \\
\hline
\end{tabular}

there is no association between the types of cancer according to ICD-10 and treatment clinical variables.

Table 5 shows that $13.2 \%$ of head and neck cancers occur in patients who are between 51 and 60 years of age, are found outside the oral cavity more frequently in males $(32.7 \%)$, occur in patients with low levels of education, at the sierra region; $29.8 \%$ of patients receive several treatments, with a hospital treatment time of more than 180 days, and $43.1 \%$ of patients discontinued treatment. There is no association between the anatomical region and demographic and clinical variables.

Table 6 shows that the age at which treatment is more often discontinued is $51-60$ years with $14.2 \%$, the male gender with $33.6 \%$, sierra region residents with $51.1 \%$. Among the subjects with cancer outside the oral cavity, $43.1 \%$ received a single treatment, and $34.5 \%$ received treatment for more than 180 days. The level of significance of received treatments is 0.006 ; therefore, there is an association between treatment evolution and the treatment received.

\section{Discussion}

Cancer is a public health problem, with individuals with low socioeconomic levels being the most vulnerable. According to Arias et al. ${ }^{25}$, head and neck cancer ranks seventh in mortality in the world, accounting for approximately 375,000 deaths per year, out of which $5.8 \%$ occur in Latin America. This is the first study on the prevalence of head and neck cancer carried out at Eugenio Espejo Specialty Hospital, in Ecuador, where a slight prevalence of the female gender was recorded, with $50.71 \%$ of treated cases; this higher incidence may be a consequence of changes that have appeared in recent years in women's behavior and quality of life, such as poor diet, increased consumption of tobacco and alcohol and certain sexual behaviors at early ages, and in the case of housewives, it could be due to a constant use of chemicals for cleaning and disinfection. The WHO and studies carried out by Pereira et al. ${ }^{26}$, Oreggioni et al. ${ }^{7}$ and Posada et al. ${ }^{23}$ refer a predominance of the male gender.

Several studies have determined that head and neck cancer patients mean age is $60 \pm 5$ years, and that incidence increases when approaching 40 years of age. In this study, the age group was 11-93 years, with a mean of $55 \pm 5$ years, data that are consistent with those of other studies conducted by Vinitzky et al. ${ }^{27}$ (average age of 60.5 years), Oreggioni et al. ${ }^{7}$ (mean age, $55 \pm 12$ years) and Posada et al. ${ }^{23}$ (63.5 years). Alan et al. ${ }^{28}$, in their study carried out in India, report a higher percentage for the age group of 51 to 60 years.

Studies of head and neck cancer have demonstrated that patients with low levels of education who belong 


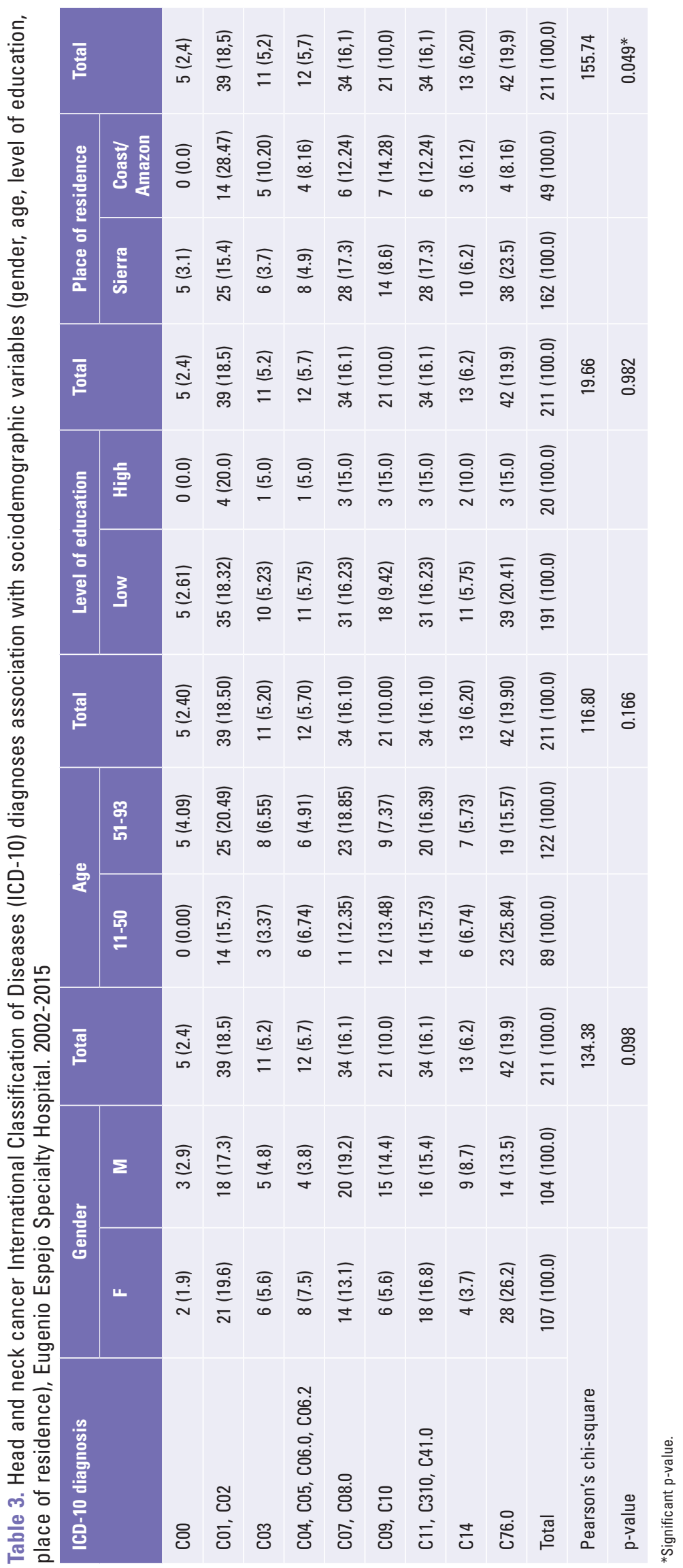


Table 4. Head and neck cancer International Classification of Diseases (ICD-10) diagnoses association with clinical variables. Eugenio Espejo Specialty Hospital. 2002-2015

\begin{tabular}{|c|c|c|c|c|c|c|c|c|c|}
\hline \multirow{2}{*}{$\begin{array}{l}\text { ICD-10 } \\
\text { diagnosis }\end{array}$} & \multicolumn{3}{|c|}{ Treatment type } & \multicolumn{3}{|c|}{ Hospital treatment time } & \multicolumn{3}{|c|}{ Treatment evolution } \\
\hline & Single & Several & Total & $1-180$ days & +180 days & Total & $\begin{array}{l}\text { Continue } \\
\text { on } \\
\text { treatment }\end{array}$ & $\begin{array}{c}\text { Discontinued } \\
\text { treatment }\end{array}$ & Total \\
\hline $\mathrm{COO}$ & $4(3.88)$ & $1(0.92)$ & $5(2.40)$ & $1(1.1)$ & $4(3.4)$ & $5(2.4)$ & $0(0.00)$ & $5(3.59)$ & $5(2,40)$ \\
\hline $\mathrm{C} 01, \mathrm{CO} 2$ & $14(13.59)$ & $25(23.14)$ & $39(18.50)$ & $19(20.2)$ & $20(17.09)$ & $39(18.5)$ & $17(23.60)$ & $22(15.82)$ & $39(18,50)$ \\
\hline $\mathrm{CO3}$ & $3(2.91)$ & $8(7.40)$ & $11(5.20)$ & $5(5.3)$ & $6(5.12)$ & $11(5.2)$ & $5(6.90)$ & $6(4.31)$ & $11(5,20)$ \\
\hline $\begin{array}{l}\text { C04, C05, } \\
\text { C06.0, C06.2 }\end{array}$ & $4(3.88)$ & $8(7.40)$ & $12(5.70)$ & $5(5.3)$ & $7(5.98)$ & $12(5.7)$ & $6(8.30)$ & $6(4.31)$ & $12(5,70)$ \\
\hline $\mathrm{C} 07, \mathrm{C} 08.0$ & $18(17.47)$ & $16(14.81)$ & $34(16.10)$ & $13(13.8)$ & $21(17.94)$ & $34(16.1)$ & $11(15.30)$ & $23(16.54)$ & $34(16,10)$ \\
\hline Co9, C10 & $8(7.76)$ & $13(12.03)$ & $21(10.00)$ & $6(6.4)$ & $15(12.82)$ & $21(10.0)$ & $9(12.50)$ & $12(8.63)$ & $21(10,00)$ \\
\hline $\begin{array}{l}\text { C11, C310, } \\
\text { C41.0 }\end{array}$ & $17(16.50)$ & $17(15.74)$ & $34(16.10)$ & $20(21.3)$ & $14(11.96)$ & $34(16.1)$ & $9(12.50)$ & $25(17.98)$ & $34(16,10)$ \\
\hline C14 & $8(7.76)$ & $5(4.62)$ & $13(6.20)$ & $8(8.5)$ & $5(4.27)$ & $13(6.2)$ & $2(2.80)$ & $11(7.91)$ & $13(6,20)$ \\
\hline C76.0 & $27(26.21)$ & $15(13.88)$ & $42(19.90)$ & $17(18.1)$ & $25(21.36)$ & $42(19.9)$ & $13(18.10)$ & $29(20.86)$ & $42(19,90)$ \\
\hline Total & $103(100)$ & $108(100)$ & $211(100.0)$ & $94(100.0)$ & $117(100.0)$ & $211(100.0)$ & $72(100.0)$ & $139(100.0)$ & $211(100,0)$ \\
\hline \multicolumn{2}{|c|}{ Pearson's chi-square } & & 138.27 & & & 88.63 & & & 99.83 \\
\hline \multicolumn{2}{|l|}{$\mathrm{p}$-value } & & 0.086 & & & 0.371 & & & 0.266 \\
\hline
\end{tabular}

to low economic strata are the most vulnerable for the development of cancer. According to the levels of education, Moraes et al. ${ }^{29}$, in Brazil, found that the "none, primary and secondary" education level was $97.1 \%$, which shows some similarity with our study, where $90.52 \%$ of subjects were observed to belong to the "none, primary and secondary" education level. These data are consistent with different studies, and it could be that this high percentage is related to the low knowledge by patients on the disease itself, risk factors, symptoms and the care they should have to prevent cancer, which turns them into a vulnerable group with limited access to early diagnosis.

It is important emphasizing that cancer manifests itself at different anatomical regions and that it can be related to different lifestyles, ethnicity, gender, genetics and also be influenced by the geographical and environmental conditions of each region. Ecuador is a country with great geographical, social, cultural and environmental diversity and, owing to its location, it is a territory that lies between both hemispheres. The climate is varied, it has access to the Pacific Ocean, the Amazon, the Galapagos Islands and the Andes Mountain Range, which gives rise to the formation of four regions, namely, the coastline or coast, the mountains (sierra), the Amazon and insular region. For the purposes of our study, the sierra, coast and East regions were considered; data were dichotomized according to certain characteristics: in the sierra region, there are cold and high mountains in relation to the coast, and in the Amazon region there are areas with a tropical and hot climate. A high proportion of patients $(76.78 \%)$ were found to come from the sierra region. This higher prevalence in the sierra region may be due to the fact that the Eugenio Espejo Specialties Hospital is a state health center and is located at the sierra region (Quito, Ecuador), which makes for it to be closer and more accessible for people who live near this place, although, nevertheless, it is a national reference center.

Different studies report that some types of occupation, trades or activities can be associated with certain types of cancer. Alvarenga et al..$^{30}$, in Brazil, in an epidemiological study of head and neck cancer according to occupation, determined that it is more prevalent in patients who are farmers and in those engaged in household chores, a similar situation to that observed in the present study, where $22.7 \%$ are farmers and $38.4 \%$ are dedicated to household chores. These population groups may be more affected perhaps due to 
Table 5. Head and neck cancer anatomical region association with demographic and clinical variables. Eugenio Espejo Specialty Hospital. 2002-2015

\begin{tabular}{|c|c|c|c|c|}
\hline & \multicolumn{2}{|c|}{ Head and neck cancer } & \multirow[t]{2}{*}{ Total } & \multirow[t]{2}{*}{ p-value } \\
\hline & Non-oral cavity & Oral cavity & & \\
\hline $\begin{array}{l}\text { Age } \\
11-20 \\
21-30 \\
31-40 \\
41-50 \\
51-60 \\
61-70 \\
71-80 \\
81-93\end{array}$ & $\begin{array}{c}10(4.7) \\
14(6.6) \\
14(6.6) \\
20(9.4) \\
28(13.2) \\
21(9.9) \\
17(8.0) \\
10(4.7)\end{array}$ & $\begin{array}{c}2(0.9) \\
12(5.6) \\
11(5.2) \\
6(2.8) \\
15(7.1) \\
9(4.2) \\
14(6.6) \\
8(3.7)\end{array}$ & $\begin{array}{c}12(5.7) \\
26(12.3) \\
25(11.8) \\
26(12.3) \\
43(20.4) \\
30(14.2) \\
31(14.7) \\
18(8.5)\end{array}$ & 0.356 \\
\hline $\begin{array}{l}\text { Gender } \\
\text { Males } \\
\text { Females }\end{array}$ & $\begin{array}{l}69(32.7) \\
65(30.8)\end{array}$ & $\begin{array}{l}35(16.5) \\
42(19.9)\end{array}$ & $\begin{array}{l}104(49.2) \\
107(50.7)\end{array}$ & 0.242 \\
\hline $\begin{array}{l}\text { Level of education } \\
\text { Low } \\
\text { High }\end{array}$ & $\begin{array}{c}123(58.2) \\
11(5.21)\end{array}$ & $\begin{array}{c}68(32.2) \\
9(4.2)\end{array}$ & $\begin{array}{c}191(90.5) \\
20(9.4)\end{array}$ & 0.275 \\
\hline $\begin{array}{l}\text { Place of residence } \\
\text { Coast/Amazon } \\
\text { Sierra }\end{array}$ & $\begin{array}{c}26(12.3) \\
108(51.1)\end{array}$ & $\begin{array}{c}23(10.9) \\
54(25.59)\end{array}$ & $\begin{array}{c}49(23.2) \\
162(76.7)\end{array}$ & 0.06 \\
\hline $\begin{array}{l}\text { Treatment received } \\
\text { Several treatments } \\
\text { One treatment }\end{array}$ & $\begin{array}{l}63(29.8) \\
71(33.6)\end{array}$ & $\begin{array}{l}45(21.3) \\
32(15.1)\end{array}$ & $\begin{array}{l}108(51.1) \\
103(48.8)\end{array}$ & 0.073 \\
\hline $\begin{array}{l}\text { Hospital treatment time } \\
\text { More than } 180 \text { days } \\
1 \text { to } 180 \text { days }\end{array}$ & $\begin{array}{l}75(35.5) \\
59(27.9)\end{array}$ & $\begin{array}{l}42(19.9) \\
35(16.5)\end{array}$ & $\begin{array}{c}117(55.4) \\
94(44.5)\end{array}$ & 0.477 \\
\hline $\begin{array}{l}\text { Treatment evolution } \\
\text { Discontinued } \\
\text { Continued }\end{array}$ & $\begin{array}{l}91(43.1) \\
43(20.3)\end{array}$ & $\begin{array}{l}48(22.7) \\
29(13.7)\end{array}$ & $\begin{array}{l}139(65.8) \\
72(34.12)\end{array}$ & 0.25 \\
\hline Total & $134(63.5)$ & 77 (36.4) & $211(100.0)$ & \\
\hline
\end{tabular}

lack of knowledge about the disease and low levels of education, and cancer at early stages is asymptomatic, which is why many people are diagnosed and treated when the disease is at advanced stages. Farmers are exposed or related to the soil, the sun and certain environmental changes for the longest periods. Those dedicated to housework are people who work at home, generally they are women, and for the cleaning and disinfection of their houses they are constantly exposed to certain substances that may or may not generate smoke, dust and chemicals, such as disinfectants, especially chlorine at high concentrations.

To identify the type of cancer in our study, ICD-10 was used, the codes of which are used at Eugenio Espejo hospital: $19.9 \%$ of patients with head and neck cancer correspond to code $\mathrm{C} 76.0$ (this code is used to designate neoplasms that have no specific location or because they correspond to cancers associated with large anatomical extensions), followed by malignant neoplasm of the tongue (C01-C02) with $18.5 \%$ and salivary glands (C07-C08.0), which accounted for 16.1\% of cases, with oral cavity being the anatomical location most affected by cancer, with $36.5 \%$, followed by the salivary glands with $16.1 \%$ and the oropharynx with $10 \%$. Similar data were found in the studies carried out by Ordóñez et al. ${ }^{31}$, Álvarez Arias et al. ${ }^{25}$ and Oreggioni et al.?.

Depending on the type and stage of cancer, treatments could be single or combined, as reported by Posada et al. ${ }^{23}$ and Vargas et al. ${ }^{9}$, with their observations being similar to those in our study, where combined treatments accounted for $51.18 \%$, and surgery as the only treatment for $48.82 \%$.

On the other hand, $44.5 \%$ of patients had a hospital treatment time of 1 to 180 days, a period that was considered from the first day the patient attends for 
Table 6. Association of head and neck cancer treatment evolution with demographic and clinical variables. Eugenio Espejo Specialty Hospital. 2002-2015

\begin{tabular}{|c|c|c|c|c|}
\hline & \multicolumn{2}{|c|}{ Head and neck cancer } & \multirow{2}{*}{$\begin{array}{c}\text { Total } \\
(\%)\end{array}$} & \multirow[t]{2}{*}{$\mathbf{p}$} \\
\hline & Discontinued treatment & $\begin{array}{l}\text { Continued } \\
\text { treatment }\end{array}$ & & \\
\hline $\begin{array}{l}\text { Age } \\
11-20 \\
21-30 \\
31-40 \\
41-50 \\
51-60 \\
61-70 \\
71-80 \\
81-93\end{array}$ & $\begin{array}{c}10(4.7) \\
15(7.1) \\
15(7.1) \\
16(7.5) \\
30(14.2) \\
19(9.0 \\
21(9.9) \\
13(6.1)\end{array}$ & $\begin{array}{c}2(0.9) \\
11(5.2) \\
10(4.7) \\
10(4.7) \\
13(6.1) \\
11(5.2) \\
10(4.7) \\
5(2.3)\end{array}$ & $\begin{array}{c}12(5.7) \\
26(12.3) \\
25(11.8) \\
26(12.3) \\
43(20.4) \\
30(14.2) \\
31(14.7) \\
18(8.5)\end{array}$ & 0.823 \\
\hline $\begin{array}{l}\text { Gender } \\
\text { Males } \\
\text { Females }\end{array}$ & $\begin{array}{l}71(33.6) \\
68(32.2)\end{array}$ & $\begin{array}{l}33(15.6) \\
39(18.4)\end{array}$ & $\begin{array}{l}104(49.2) \\
107(50.7)\end{array}$ & 0.282 \\
\hline $\begin{array}{l}\text { Level of education } \\
\text { Low } \\
\text { High }\end{array}$ & $\begin{array}{c}124(58.7) \\
15(7.1)\end{array}$ & $\begin{array}{c}67(31.7) \\
5(2.3)\end{array}$ & $\begin{array}{c}191(90.5) \\
20(9.4)\end{array}$ & 0.26 \\
\hline $\begin{array}{l}\text { Place of residence } \\
\text { Coast/Amazon } \\
\text { Sierra }\end{array}$ & $\begin{array}{c}31(14.6) \\
108(51.1)\end{array}$ & $\begin{array}{c}18(8.5) \\
54(25.5)\end{array}$ & $\begin{array}{l}49(23.22) \\
162(76.7)\end{array}$ & 0.391 \\
\hline $\begin{array}{l}\text { Anatomical region } \\
\text { Other regions } \\
\text { Oral cavity }\end{array}$ & $\begin{array}{l}91(43.1) \\
48(22.7)\end{array}$ & $\begin{array}{l}43(20.3) \\
29(13.7)\end{array}$ & $\begin{array}{l}134(63.5) \\
77(36.4)\end{array}$ & 0.25 \\
\hline $\begin{array}{l}\text { Treatment received } \\
\text { Several treatments } \\
\text { One treatment }\end{array}$ & $\begin{array}{l}62(29.3) \\
77(36.4)\end{array}$ & $\begin{array}{l}46(21.8) \\
26(12.3)\end{array}$ & $\begin{array}{l}108(51.1) \\
103(48.8)\end{array}$ & 0.006 \\
\hline $\begin{array}{l}\text { Hospital treatment time } \\
\text { More than } 180 \text { days } \\
1 \text { to } 180 \text { days }\end{array}$ & $\begin{array}{l}73(34.5) \\
66(31.2)\end{array}$ & $\begin{array}{l}44(20.8) \\
28(13.2)\end{array}$ & $\begin{array}{l}117(55.4) \\
94(44.5)\end{array}$ & 0.148 \\
\hline Total & $139(65.8)$ & $72(34.1)$ & $211(100.0)$ & \\
\hline
\end{tabular}

diagnosis and treatment to the last date recorded in the medical record, with some patients having remained under treatment for more than two years. Treatment was completed by $31.8 \%$ of patients, $25.6 \%$ discontinued treatment, $8.5 \%$ died while on treatment and $34.1 \%$ continued on treatment. It is important to emphasize that, for this study, data were collected up to December 31, 2015; as it can be observed, there was a larger influx of head and neck cancer patients that were treated during the years 2013, 2014 and 2015; therefore, many continued under treatment.

This epidemiological study has been highly important, since it allowed obtaining certain statistical data and thereby knowing which are the most vulnerable groups, in order to implement education and care actions that people should take before this disease is triggered or progresses. Furthermore, given that this is a public health problem, it is necessary to work together with private institutions in order to adopt the necessary measures to prevent, educate and direct people to the right place for the required treatment and care.

\section{Acknowledgements}

The author thanks the Eugenio Espejo Specialty Hospital, especially the Head of the Oncology Department, Dr. Ahmad Wali Mushtaq Wali.

\section{Funding}

The authors did not receive any sponsoring to carry out this article. 


\section{Conflict of interests}

The authors declare that they have no conflicts of interest.

\section{Ethical disclosures}

Protection of human and animal subjects. The authors declare that no experiments were performed on humans or animals for this research.

Confidentiality of data. The authors declare that they have followed the protocols of their work center on the publication of patient data.

Right to privacy and informed consent. The authors declare that no patient data appear in this article.

\section{References}

1. Granados García M, Herrera Gómez Á. Manual de oncología. Procedimientos médicos quirúrgicos. Cuarta Ed. México: McGraw-Hill; 2010. pp. 1-9.

2. Ariosa Argüelles C, González F, Rodríguez G, Rodríguez J. Cáncer bucal. Estudio de cinco años. Revista Médica Electrónica [Internet]. 2006;28 (6). Disponible en: http://www.revmedicaelectronica.sld.cu/index. $\mathrm{php} / \mathrm{rme} /$ article/view/349

3. Moctezuma-Bravo GS, Díaz de León-Medina R, Rodríguez-Quilantan FJ Moctezuma-Dávila M. Cáncer oral en un hospital general de zona del Instituto Mexicano del Seguro Social en México, (1988-2005). Gac Mex Oncol. 2015;14(6):323-8.

4. Navarro Expósito F, López González JL, Álvarez-Mon Soto M. Cáncer de cabeza y cuello. Med - Programa Form Médica Contin Acreditado [Internet]. 2017;12(31):1833-48. Disponible en: http://linkinghub.elsevier. com/retrieve/pii/S0304541217300872

5. Gallegos-Hernández JF. Cáncer de cabeza y cuello. Gac Mex Oncol. 2015;14(1):1-2.

6. Gallegos Hernández JF, Ortiz Maldonado AL, Rojas Orellana S, Flores Díaz R, Espinoza Velazco A, Minauro Muñoz GG. Factores pronóstico en cáncer de boca. Acta Médica Grupo Ángeles. 2010;8(2):88-94.

7. Oreggioni Aldama L, Ortíz L, Joy L, Moringo M. Desnutrición a partir de la valoración global subjetiva generada por el paciente (VGS-GP) en pacientes con cáncer de cabeza y cuello. Mem Inst Investig Cienc Salud. 2016;14(1):86-93.

8. Coca Granado MR, Jiménez Rodríguez Y. El cáncer de cabeza y cuello: un problema social. Acta Med Cent. 2015;9(4):112-6.

9. Vargas-Soto O, Molina-Fechero M, Castañeda-Castaneira E, Bolonga-Molina R, Carreón-Burciaga R, González-González R. Carcinomas de cabeza y cuello, experiencia de un Centro Oncológico del Estado de Durango, México. Rev ADM. 2016;73(4):190-6.

10. Ferlay J, Soerjomataram I, Ervik M, Dikshit R, Eser S, Mathers C, et al. GLOBOCAN 2012 v1.0. Cancer Incidence and Mortality Worldwide: IARC CancerBase. No. 11 [Internet]. Lyon, France: International Agency for Research on Cancer; 2013. Disponible en: http://globocan.iarc.fr

11. Biazevic MGH, Castellanos RA, Antunes JLF, Michel-Crosato E, Crosato EM. Tendências de mortalidade por câncer de boca e orofaringe no Município de São Paulo, Brasil, 1980/2002. Cad Saúde Pública, Rio Janeiro [Internet]. 2006;22(10):2105-14. Disponible en: http://www.scielo.br/ scielo.php?script=sci_arttext\&pid=S0102-311X2006001000016\&nrm=iso
12. Koontongkaew S. The tumor microenvironment contribution to development, growth, invasion and metastasis of head and neck squamous cell carcinomas. J Cancer. 2013;4(1):66-83.

13. Sepiashvili L, Hui A, Ignatchenko V, Shi W, Su S, Xu W, et al. Potentially novel candidate biomarkers for head and neck squamous cell carcinoma identified using an integrated cell line-based discovery strategy. Mol Cell Proteomics. 2012:11(11):1404-15.

14. Abreu de Aquino R, Lopes M, Ximenes de Menezes C, Rodrígues M. Alterações fonoaudiológicas e acesso ao fonoaudiólogo nos casos de óbito por câncer de lábio, cavidade oral e orofaringe: um estudo retrospectivo. Rev CEFAC [Internet]. 2016;18(3):737-45. Disponible en: http:// www.scielo.br/scielo.php? script $=$ sci_arttext \& pid $=S 1516$ $18462016000300737 \&$ lng $=$ pt\&tlng=pt

15. Cardemil MF. Epidemiología del carcinoma escamoso de cabeza y cueIlo. Rev Chil Cir. 2014;66(6):614-20.

16. International Agency for Research on cancer. World cancer report 2014 [Internet]. International Agency for Research on cancer, World Health Organization; 2014. Disponible en: https://www.who.int/cancer/publications/WRC_2014/en/

17. Biazevic MGH, Antunes JLF, Togni J, de Andrade FP, de Carvalho MB, Wünsch-Filho $V$. Immediate impact of primary surgery on health-related quality of life of hospitalized patients with oral and oropharyngeal cancer. J Oral Maxillofac Surg. 2008;66(7):1343-50.

18. Pinaki B, Brockton NT, Dort JC. Head and neck cancer: From anatomy to biology. Int J Cancer. 2013;133(9):2013-23.

19. Parkin DM, Pisani P, Ferlay J. Global Cancer Statistics. CA Cancer J Clin. 1999;49(1):33-64.

20. Torre L, Bray F, Siegel RL, Ferlay J, Lortet-Tieulent J, Jemal A. Global Cancer Statistics, 2012. CA Cancer J Clin. 2015;65(2):87-108.

21. Kocaelli H, Apaydin A, Aydil B, Ayhan M, Karadeniz A, Ozel S, et al. Evaluation of potential salivary acetaldehyde production from ethanol in oral cancer patients and healthy subjects. Hippokratia. 2014;18:269-74.

22. Rocha Buelvas A. Cáncer oral: El papel del odontólogo en la detección temprana y control. Rev Fac Odontol Univ Antioq. 2009;21(1):112-21.

23. Posada-López A, Palacio M, Salas C, Álvarez E, Grisales H. Survival rate of oral squamous cell carcinoma patients treated for the first time in cancer centers between 2000 and 2011, Medellín-Colombia. Rev Fac Odontol Univ Antioq. 2016;27(2):245-61.

24. Sociedad de Lucha Contra el Cáncer QE. Registro Nacional De Tumores/ National Cancer Registry. Epidemiología del cáncer en Quito 2006-2010 [Internet]. Quito, Ecuador: Sociedad de Lucha contra el Cáncer QE; 2014. Disponible en: http://www.estadisticas.med.ec/Publicaciones/PUBLICACION-QU-2006-2010.pdf

25. Arias DÁ, Estefan AM, Borche G, Albora RD, Sande VR, Cuello M. Cáncer de cabeza y cuello en Uruguay. Análisis de sobrevida en dos centros de referencia. 2018;34(1):21-8. Disponível em: http://dx.doi.org/10.29193/rmu.34.1.2

26. Pereira IF, Reimar V, de Souza Noronha A, Drummond M, Mara T, Amaral $P$, et al. Neoplasias malignas em região de cabeça e pescoço: perfil dos pacientes atendidos na UFMG. Rev Cubana Estomatol. 2016;53(4).

27. Vinitzky Brener I, Ibáñez Mancera NG, Eljure Eljure E, Bravo FA. Retraso en el diagnóstico de cáncer en cavidad bucal y anexos como factor clave para el pronóstico. Rev ADM. 2014;71(4):188-91.

28. Alam M, Siddiqui S, Perween R. Epidemiological profile of head and neck cancer patients in Western Uttar Pradesh and analysis of distributions of risk factors in relation to site of tumor. J Cancer Res Ther. 2017;13(3):430-5.

29. Costa de Moraes R, Dias F, Marcelo da Silva C, Guimäraes Fischer R. Association between chronic periodontitis and oral/oropharyngeal cancer. Braz Dent. 2016;27(3):261-6.

30. Alvarenga L, Ruiz M. Avaliação epidemiológica de pacientes com câncer de cabeça e pescoço em um hospital universitário do noroeste do estado de São Paulo. Braz J Otorhinolaryngol. 2008; 74(1):68-73.

31. Ordóñez D, Aragón N, García LS, Collazos P, Bravo LE. Cáncer oral en Santiago de Cali, Colombia: análisis poblacional de la tendencia de incidencia y mortalidad. Salud Publica Mex. 2014;56(5):465-72. 